operations." 9 At the very least then, there is then a growing self-consciousness on behalf of the United Nations that it cannot continue taking an ad-hoc approach to the issue of accountability, but the perception that has been fostered that the United Nations somehow considered itself above the law has been very damaging to its reputation.

\title{
IMPARTIALITY
}

When serving as an intermediary between two opposing sides, the ability of an international organization to remain impartial is relatively easy. However, in those situations in which an international organization goes in to change the existing governance and is more intermixed with the local population and local institutions, the problem in remaining truly impartial is more pronounced.

In these latter situations, the same dual role played by international officials discussed above comes into play. On the one hand, officials are acting on behalf of the international organization, yet on the other, they are acting as the local government. And governments, by their very definition, are biased toward the best interest of the state. It therefore becomes impossible for officials of international organizations to simultaneously represent all members of the international community while also promoting the interests of one state. An example of this was seen in the negotiations that occurred between East Timor and Australia over the oil and gas resources in the area known as the Timor Gap: UNTAET was actively involved in getting the best deal for East Timor, which ran expressly contrary to its role as an international organization.

Overall, by examining the legitimacy of international organizations to carry out territorial administration, it becomes clear that there are reasons to doubt that they are somehow inherently better suited for these activities. It may be the case that ITA will never be wholly legitimate or supportable on a normative level. One question that remains, however, is whether the United Nations is perhaps the least illegitimate actor for territorial administration for which we can hope.

Regardless of whether future missions follow Afghanistan's "light footprint" approach or replicate the intrusiveness associated with East Timor and Kosovo, the United Nations is clearly making plans to continue these operations in the future, as evidenced by the recent establishment of the Peacebuilding Commission. ${ }^{10}$ At a minimum, these missions must be constructed in such a way to take into account a wider range of actors and interests, while at the same time working to resolve some of these acknowledged gaps in legitimacy.

\section{What's So Special About Transitional Justice? Prolegomenon for an Excuse-Centered Approach to Transitional Justice}

\section{By David C. Gray*}

"Transitional justice", asks what successor regimes, committed to human rights and the rule of law, can and should do to seek justice for widespread and institutional atrocities perpetrated by and under their predecessors. Although the challenges of transitional justice

\footnotetext{
${ }^{9}$ In Larger Freedom: Towards Development, Security and Human Rights for All, Report of the Secretary-General, UN Doc. A/59/2005 \& annex, para. 113 (2005), available at <http://www.un.org/largerfreedom/contents.htm>.

${ }^{10}$ Implementation of the International Strategy for Disaster Reduction, Report of the Secretary-General, UN Doc. A/60/180 (2005), available at <http://documents.un.org>.

*Duke University School of Law. Some of the views expressed here are elaborated in David Gray, An ExcuseCentered Approach to Transitional Justice, 74 ForD. L. REv. 2621 (2006).
} 
are not new, ${ }^{1}$ the subject has come to the fore with the rise of an international human rights culture and the decline of Apartheid, colonialism, and communist autocracy. The fundamental challenge for transitional regimes is a disparity between needs and resources. In addition to justice, new governments must ensure the peace, achieve stability, reform public institutions, repair infrastructure, and institutionalize commitments to human rights and the rule of law. These demands are extraordinary and, even with aid from friendly states and international institutions, all transitions must make difficult decisions. Some of the most troubling are presented by justice initiatives.

The understandable instinct in the face of mass violence is to prosecute everyone responsible. Unfortunately, this is almost always impossible. Atrocities on a scale that calls for transition require the participation and complicity of tens, and often hundreds, of thousands of individuals, agencies, and corporations. The resources-material, human, institutional, and political-needed to prosecute all candidates far exceed those available to transitional regimes and must compete with efforts to achieve other transitional goals, including stability and security. Confronted with this reality, most transitions pursue hybrid approaches to justice composed of limited prosecutions, amnesties, truth commissions, institutional reform, reparations, vetting, and reconciliation. These efforts are notoriously ad hoc, however, leaving transitions with the sense that they are settling for the best possible justice, all things considered.

Although hybrid programs, and particularly truth commissions, have been celebrated in transitions from South Africa to Peru, they are pursued in the shadow of prosecutions, leaving supporters to regret justice lost. In an effort to quiet these sighs and defend against critics much of the transitional justice literature is dedicated to elaborating gap-filling theories, such as restorative justice. These efforts have been the target of numerous critiques, but the most probing argue that there is nothing extraordinary about transitional justice. ${ }^{2}$ That is, although the challenges to justice in transitions are more severe than those found in stable states, they have the same fundamental character, so there is no need to construct unique theories of transitional justice. Rather, theorists and practitioners should consult the lessons of ordinary justice and accept the burdens of inevitable imperfection. ${ }^{3}$

Reference to the travails of ordinary justice fails utterly to comprehend the unique features of abusive regimes and subsequent transitions to democracy. Specifically, it neglects the role that black letter law, institutional practice, social ontology, and historical teleologycollectively "the public face of law"-play in programs of mass violence. In stable states, assault, rape, and murder are relatively infrequent and are broadly condemned. By contrast, abusive regimes are identified by widespread abuses directed against a targeted group. Although selective prosecutions habitually focus on those "most responsible," the grueling labors of violence are carried out by cadres of willing executioners ${ }^{4}$ with the knowledge, support, and assistance of public personalities, ${ }^{5}$ including the military, police, political leaders,

\footnotetext{
1 Jon Elster, Closing the Books: Transitional Justice in Historical Perspective, 3-21 (2004).

${ }^{2}$ See Eric Posner \& Adrian Vermeule, Transitional Justice as Ordinary Justice, 117 HARv. L. Rev. 761 (2004). ${ }^{3}$ Id.

${ }^{4}$ Daniel Goldhagen, Hitler's Willing Executioners (1996). There are many implicated in mass violence who were not so willing, of course. In all abusive regimes there are those who actively oppose. It remains the case, however, that atrocities require the support of thousands of participants, passive supporters, opportunistic profiteers, and those who indulge in naive denial. While we may applaud the heroes, we are left to wonder how so many were led to such madness. The key to answering this question is to take seriously the possibility that the practical realities of scale and complicity that distinguish abusive regimes are not merely the same problems that face "ordinary justice"' on a different scale but, rather, mark unique social conditions that carry normative force.

${ }^{5}$ Id. at $164-78$.
} 
and members of the media. ${ }^{6}$ These diverse agents are not independent entrepreneurs. Rather, their activities are organized by an abusive public face of law that sustains in abusers a sense of justification by presenting a view of the world in which victims are subhumans and by advancing a vision of the end of history in which the victims have been eliminated.

The role played by an abusive public face of law in pre-transitional regimes is what makes mass atrocities special and, in turn, makes transitional justice unique. Stable state crimes are perpetrated by independent, self-interested agents who act in conscious violation of the prevailing public face of law. By contrast, pretransitional abuses are conducted with the direction and support of an abusive public face of law. Attempts to deal with the challenges of transitional justice run up against a wall because they fail to take seriously these defining conditions. Only by taking normative account of these unique circumstances can practitioners and theorists begin to understand what makes transitional justice special. Only after these conditions are understood can those interested in seeking justice in transitions begin to develop a theoretically and practically sustainable transitional jurisprudence.

The fact that past wrongs enjoyed official and social approval presents significant deontological and consequentialist challenges to criminal trials in transitions to democracy. ${ }^{7}$ In particular, transitional dedication to the rule of law $^{8}$ requires faith to the legality principle. ${ }^{9}$ Rendered as nulla poena sine lege, the principle prohibits states from punishing acts that were not against the law at the time they were committed. In light the role of an abusive public face of law in organizing, justifying, and sustaining pretransitional abuses, transitional regimes must recognize that the principle of legality imposes significant limitations on criminal prosecutions during transition. The principle prohibits retroactive enforcement of law. Agents under the law must be warned that their actions are at risk of punishment. By definition, abuses in ancien regimes ${ }^{10}$ were not under such a threat. Thus, transitional courts cannot punish pretransitional abuses insofar as they were consistent with the pretransitional public face of law. To conduct criminal trials in these conditions would be to violate a foundational principle of the rule of law.

This position may seem unappealing, to say the least. After all, murder, rape, assault, and torture were against the laws on the books in even the worst regimes and, at any rate, these are acts so immoral that everyone has a duty to refrain. Given these facts, it seems wrong, if not nauseating, to suggest that those who engaged in atrocities ought not to be prosecuted. There are three responses worth considering in the face of these concerns.

First, the "public face of law" is not the same as black-letter law. In many regimes laws on the books prohibit murder, rape, and other acts of violence. ${ }^{11}$ Unfortunately, "in transitional periods, there is commonly a large gap between the law as written and as it is perceived.", 12

\footnotetext{
${ }^{6}$ See Prosecutor v. Nahimana, Barayagwiza, Ngeze, Judgment and Sentence, No. ICTR-99-52-T (Dec. 3, 2003).

${ }^{7}$ Miriam Aukerman, Extraordinary Evil Ordinary Crime: A Framework for Understanding Transitional Justice, 15 HaRv. Hum RTs. L.J. 59, 75 (2002).

${ }^{8}$ Elster, supra note 1 , at $83,235-40$; Martha Minow, Between Vengeance and Forgiveness $25,30-37$ (1996); MARTIN Golding, Retroactive Legislation and Restoration of the Rule of Law, ANN. REv. L. \& ETHICS, 170-74 (1996).

${ }^{9}$ ANDREW Ashworth, Principles of Criminal LaW 70-74 (4th ed. 2003); William Blackstone, CommentaRIES ON THE LaWS OF ENGLANd 45-47 (1765-1769); Lon Fuller, The Morality of LaW 39, 248-49 (1969); Jerome Hall, General Principles of Criminal Law 27-69 (2d ed. 1960); Herbert Packer, The Limits of the Criminal Sanction 79-87 (1968); Lon Fuller, Positivism and Fidelity to Law-A Reply to Professor Hart, 71 HaRV. L. REV. 630, 650-51 (1958) [hereinafter Reply].

${ }^{10}$ I take this term from Ruti Teitel, Transitional Justice (2000).

${ }^{11}$ Sanford Levinson, Trials, Commissions, and Investigating Committees, in Truth v. Justice: The Morality of Truth Commissions 211, 219 (Robert 1. Rotberg \& Dennis Thompson eds., 2000).

${ }^{12}$ Tertel, supra note 10, at 19.
} 
This perception, which reflects the reality of what law is in abusive regimes, is regulated by social and institutional elements of the public face of law, which affect perceptions of what is and is not prohibited ${ }^{13}$ and, perhaps more importantly, who is and who is not subject to legal protection. ${ }^{14}$ So, although there were laws on the books against assault and murder in antebellum slave states, they did not provide effective protection for slaves, who were considered chattel. ${ }^{15}$ Similarly, in abusive regimes, the targeting of certain classes of victims is sanctioned by prevailing beliefs regarding who is and who is not included in the class of beings who enjoy the protections afforded by laws against murder, rape, and assault.

Second, the principle of legality addresses itself to the state's privilege to punish, not individual agents' duties to discover the moral truth. Under the principle of legality, governments have the burden of defining legal duty by fair, consistent, and predictable use of force. The limit of an agent's public duty under the law is to understand the normative guidelines enforced by official threats of force and to conduct themselves appropriately. Where a legal agent has fulfilled this duty, punishment is unjustified. Moral duties have a different structure, putting agents in direct contact with the moral law. However, violation of moral duties cannot alone justify legal punishment. The legality excuse reflects a split between moral and public agency and the corresponding division between moral and legal blame. Legality concerns are limited to criminal punishment, leaving plenty of room for moral guilt and consonant responsibilities for repair and reform. ${ }^{16}$

Finally, the focus on legality and public agency has positive significance for transitional jurisprudence. If mass atrocities are a function of prevailing social norms captured in an abusive public face of law, and transition, by definition, involves a wholesale shift in that normative framework accompanied by reform of public institutions, then it follows that former abusers might well act differently under the laws of a new state and should, therefore, be regarded as sites for potential change rather than as objects for blame and punishment. Given the role of an abusive public face of law in the past, it would be inefficient, pointless, and ultimately unfair to assume otherwise.

Recognizing the role of an abusive public face of law in atrocities recognizes not only the transitional potential of political, social, and legal reform, but also the transitional potential of individual abusers. Transitional jurisprudence must take normative account of these opportunities and design transitional procedures that reflect potential for change. Respecting the limits of legality is one result. An excuse-centered approach to transitional justice utilizes truth commissions to define and distribute an affirmative defense against criminal prosecution based on the legality principle. In addition, by recognizing violations of individual moral duties, it establishes the ground work for individual and collective duties of repair. ${ }^{27}$

\footnotetext{
${ }^{13}$ Id. at $18-20$.

${ }^{14}$ Abusive regimes frequently justify abuses by classifying victims such that they cannot be "murdered" or "raped." See Richard Rorty, Human Rights, Rationality, and Sentimentality, in ON Human Rights 112-14 (Stephen Shute \& Susan Hurley eds., 1993).

${ }^{15}$ See Omar Swartz, Codifying the Law of Slavery in North Carolina: Positive Law and the Slave Persona, 29 T. MARSHALL L. REv. 285, 291-300 (2004) (discussing failed prosecutions of slave owners for assault and murder). The same cannot be said of lynch mobs in the 1920s. The Reconstruction Amendments and federal criminal statutes made clear to all Americans the inherent evil of the social ontology that categorized those of African and Caribbean heritage as subhuman rather than citizens deserving of full legal protection.

${ }^{16}$ Karl Jaspers, The Question of German Guilt 67-75 (2000) (originally published as Die Schuldfrage (1947))

${ }^{17}$ An argument for absolute duties of repair based on moral and political guilt is elaborated in David Gray, A No Excuse Approach to Transitional Justice (April 13, 2006) (unpublished manuscript, on file with author).
} 